\title{
Existence, Uniqueness, and Stability Solutions of Nonlinear System of Integral Equations
}

\author{
Rizgar Issa Hasan \\ Duhok Polytechnic University, rizqar.issa@dpu.edu.krd
}

doi: https://doi.org/10.15642/mantik.2020.6.2.76-82

\begin{abstract}
Abstrak. Tujuan dari penelitian ini adalah mempelajari keberadaan, keunikan dan solusi stabilitas sistem baru nonlinier persamaan integral dengan menggunakan metode pendekatan Picard (pendekatan berurutan) dan teorema titik tetap Banach. Studi tentang persamaan integral nonlinier semacam itu bersifat lebih umum dan mendorong kita untuk memperbaiki guna memperluas hasil Butris. Teorema tentang keberadaan dan keunikan solusi ditetapkan dalam beberapa kondisi yang diperlukan dan cukup pada domain tertutup dan terbatas (ruang kompak).
\end{abstract}

Kata kunci: Metode pendekatan Picard; Teorema titik tetap Banach; Persamaan integral

\begin{abstract}
The aim of this work is to study the existence, uniqueness, and stability solutions of a new nonlinear system of integral equation by using Picard approximation (successive approximation) method and Banach fixed point theorem. The study of such nonlinear integral equations is more general and leads us to improve to extend the result of Butris. Theorems on the existence and uniqueness of a solution are established under some necessary and sufficient conditions on closed and bounded domains (compact spaces).
\end{abstract}

Keywords: Picard approximation method; Banach fixed point theorem; Integral equation 


\section{Introduction}

Integral equation has been arisen in many mathematical and engineering field, so that solving this kind of problems are more efficient and useful in many research branches. Analytical solution of this kind of equation is not accessible in general form of equation and we can only get an exact solution only in special cases. But in industrial problems we have not spatial cases so that we try to solve this kind of equations numerically in general format. Many numerical schemes are employed to give an approximate solution with sufficient accuracy $[3,4,6,10]$. Many authors create and develop Successive approximation method and Banach fixed point theorem [1, 2,5,7,8,9] and schemes to investigate the solution of integral equations describing many applications in mathematical and engineering field.

Burris [1] has been used Picard approximation (successive approximation) method and Banach fixed point theorem. which were introduced by Rama [6] to study the solution of Volterra integral equation of the second kind which has the form:

$$
u(t)=f(t)+\int_{a}^{t} F(t, s) u(s) d s .
$$

In this equation the functions $\mathrm{f}(\mathrm{t})$ and $\mathrm{F}(\mathrm{t}, \mathrm{s})$ are continuous on the interval $0 \leq \mathrm{t} \leq$ $a$ and square region $0 \leq \mathrm{t}, \mathrm{s} \leq \mathrm{b}$.

Definition 1. Let $\left\{f_{m}(t)\right\}_{m=0}^{\infty}$ be a sequence of functions defined on a set. $E \subseteq R^{1}$ We say that $\left\{f_{m}(t)\right\}_{m=0}^{\infty}$ converges uniformly to the limit function $f$ on $E$ if, given $\varepsilon>0$ there exists a positive integer $N$ such that :

$\left|f_{m}(t)-f(t)\right|<\varepsilon, \quad(m \geq N, t \in E)$

Theorem1. If $f$ is continuous on $[a, b]$ and if $F(x)=\int_{a}^{x} f(t) d t, a \leq x \leq b$, then $F(x)$ is also continuous on $[a, b]$

Definition 2. Let $f$ be a continuous function defined on a domain $G=\{(t, x): a \leq t \leq$ $b, c \leq x \leq d\}$. Then $f$ is said to satisfy a Lipschitz condition in the variable $x$ on $G$, provided that a constant $L>0$ exists with the property that $\left|f\left(t, x_{1}\right)-f\left(t, x_{2}\right)\right| \leq L\left|x_{1}-x_{2}\right|$, for all $\left(t, x_{1}\right),\left(t, x_{2}\right) \in G$. The constant $L$ is called a Lipschitz constant for $f$.

Definition 3. A solution $x(t)$ is said to be stable if for each $\varepsilon>0$,

There exists a $\delta>0$ such that any solution $\bar{x}(t)$ which satisfies

$\left\|\bar{x}\left(t_{0}\right)-x\left(t_{0}\right)\right\|<\delta$ for some $t_{0}$, also satisfies

$\|\bar{x}(t)-x(t)\|<\varepsilon \quad$ for all $t \geq t_{0}$.

Definition 4. Let $E$ be a vector space a real-valued function $\|$.$\| of E$ into $R^{1}$ called a norm if satisfies:

I. $\quad\|x\| \geq 0$ for all $x \in E$,

II. $\quad\|x\|=0$ if and only if $x=0$,

III. $\quad\|x+y\| \leq\|x\|+\|y\|$ for all $x, y \in E$,

IV. $\quad\|\alpha x\|=|\alpha|\|x\|$ for all $x \in E$ and $\alpha \in R$.

Definition 5. A linear space $E$ with a norm defined on it is called a normed space.

Definition 6. A normed linear space $E$ is called complete if every Cauchy sequence in $E$ converges to an element in.

Definition 7. A complete normed linear space is a Banach space.

Definition 8. if $T$ maps $E$ into itself and $z$ is a point of $E$ such that $T z=z$, then $z$ is a fixed point of $T$.

Definition 9. Let $(C[0, T],\|\|$.$) be a norm space if T$ maps into itself we say that $T$ is a contraction mapping on $\mathrm{C}[0, \mathrm{~T}]$ if there exists $\alpha \in R$ with $0<\alpha<1$ such that

$\|T x-T y\| \leq \alpha\|x-y\|, \quad(x, y) \in \mathrm{C}[0, \mathrm{~T}]$. 
Theorem 2. Let $E$ be a Banach space, if $T$ is a contraction mapping on $E$ then $T$ has one and only one fixed point in.

(For the definitions and theorems see $[1,5,6]$ ).

Our work is extending some results of Butris [1], by using the same method above.

Consider the following integral equation:

$u(t)=u_{0}+\int_{0}^{t} F(t, s) g(s, u(s)) d s+\int_{\alpha(t)}^{b(t)} K(t, s) u(s) d s$

Where $\mathrm{t} \in D \subseteq R^{1}$, $\mathrm{D}$ is a compact set.

Suppose the functions $g(\mathrm{t}, \mathrm{u}), a(\mathrm{t})$ and $b(\mathrm{t})$ are defined, continuous on the domain:$D=\{(\mathrm{t}, \mathrm{s}): 0 \leq \mathrm{s} \leq \mathrm{t} \leq \mathrm{b}\}$

Also the function $g(\mathrm{t}, \mathrm{u})$ and kernels $\mathrm{F}(\mathrm{t}, \mathrm{s})$ and $\mathrm{K}(\mathrm{t}, \mathrm{s})$ satisfied the following inequalities: $\|g(t, u)\| \leq M$

$\left\|g\left(t, u_{1}\right)-g\left(t, u_{2}\right)\right\| \leq L\left\|u_{1}-u_{2}\right\|$

$\int_{\alpha(t)}^{b(t)}\|\mathrm{K}(\mathrm{t}, \mathrm{s})\| \mathrm{d} \mathrm{s} \leq \mathrm{Kh}, \mathrm{h}=\|b(t)-a(t)\|$

$\|\mathrm{F}(\mathrm{t}, \mathrm{s})\| \leq N$

where $\mathrm{F}(\mathrm{t}, \mathrm{s})$ and $\mathrm{K}(\mathrm{t}, \mathrm{s})$ are kernels of the integral equation (1) and $\mathrm{M}, \mathrm{L}, \mathrm{K}, N>0$.

Define a sequence of functions $\left\{u_{m}(t)\right\}_{m=0}^{\infty}$ by

$u_{m+1}(t)=u_{0}+\int_{0}^{t} F(t, s) g\left(s, u_{m}(s)\right) d s+\int_{a(t)}^{b(t)} K(t, s) u_{m}(s) d s$

with

$u_{0}(0)=u_{0}, \mathrm{~m}=0,1,2, \ldots$.

Also define a non-empty set as follows:

$D_{f}=\mathrm{D}-\left(\mathrm{MNb}+\mathrm{Kh} \delta_{0}\right),\left\|u_{0}\right\| \leq \delta_{0}$

\section{Existence and uniqueness of solution of (1)}

In this section, we study the existence and uniqueness of equation (1) by using Picard approximation method (Successive approximation).

Theorem 3. Suppose that the integral equation (1) satisfying the inequalities (2), (3), (4), (5), (6), and relation (8). Then there exists a sequence of functions (7) converges uniformly to the limit functions $\mathrm{u}=\mathrm{u}(\mathrm{t})$ which is define by the integral equation

$u(t)=u_{0}+\int_{0}^{t} F(t, s) g(t, u(s)) d s+\int_{a(t)}^{b(t)} K(t, s) u(s) d s$

Which is a unique solution of (1).

Proof for $m=0$ in (7), we have

$\left\|u_{1}(t)-u_{0}\right\| \leq \int_{0}^{t}\left\|g\left(s, u_{0}\right)\right\|\|F(t, s)\| d s+K h \delta_{0}$

$\leq M N b+K h \delta_{0}$

So that

$\left\|u_{1}(t)-u_{0}\right\| \leq M N b+K h \delta_{0}$

for all $\mathrm{t} \in[0, b]$, i. e.

$u_{1}(t) \in D$ for all and $u_{0} \in D_{f}$.

By mathematical induction, we can prove that $u_{\mathrm{m}}(\mathrm{t}) \in \mathrm{D}$, for all $[0, b]$ and $u_{0} \in D_{f}, \mathrm{~m}=$ $1,2,3, \ldots$.

That is

$\left\|u_{m}(t)-u_{0}\right\| \leq M N b+K h \delta_{0}$

for all $t \in[0, b]$ and $u_{0} \in D_{f}$.

Next, we shall prove that (7) convergent uniformly on D.

For $m=1$ in (7), we have

$\left\|u_{2}(t)-u_{1}(t)\right\| \leq(L N b+K h)\left\|u_{1}(t)-u_{0}\right\|$

For $\mathrm{m}=2$ in (8), we have 
$\left\|u_{3}(t)-u_{2}(t)\right\| \leq(L N b+K h)^{2}\left\|u_{1}(t)-u_{0}\right\|$

And so on, by mathematical induction, we have

$\left\|u_{m+1}(t)-u_{m}(t)\right\| \leq(L N b+K h)^{m}\left\|u_{1}(t)-u_{0}\right\|$

Suppose that $\delta=(L N b+K h)<1$. Then

$\sum_{i=1}^{k}\left\|u_{m+1}(t)-u_{m}(t)\right\| \leq\left(1+\delta+\delta^{2}+\delta^{3}+\cdots \delta^{m}+\cdots\right)\left\|u_{1}(t)-u_{0}\right\| \leq \frac{1}{1-\delta}\left\|u_{1}-u_{0}\right\|$

Therefore, the sequence of functions $\left\{u_{m}(t)\right\}_{m=0}^{\infty}$ converges uniformly on the domain D.

Now, we shall prove that $u(\mathrm{t}) \in \mathrm{C}(\mathrm{D})$. Taking

$u(t)=u_{0}+\int_{0}^{t} F(t, s) g(s, u(s)) d s+\int_{a(t)}^{b(t)} K(t, s) u(s) d s$

And

$u_{m}(t)=u_{0}+\int_{0}^{t} F(t, s) g\left(s, u_{m}(s)\right) d s+\int_{a(t)}^{b(t)} K(t, s) u_{m-1}(s) d s$

Therefore,

$\left\|u(t)-u_{m}(t)\right\| \leq(L N b+K h)^{m}\left\|u_{m}(t)-u(t)\right\|$

Since $\left\{u_{m}(t)\right\}_{m=0}^{\infty}$, is convergent uniformly, then $\lim _{m \rightarrow \infty} u_{m}(t)=u(t)$.

i.e. $\left\|u_{m}(t)-u(t)\right\| \leq \epsilon_{1}$ Choosing $\epsilon_{1}=\frac{\epsilon}{L N b+K h}$, we get

$\left\|u_{m}(t)-u(t)\right\|<\epsilon$

and hence

$\mathrm{u}(\mathrm{t}) \in \mathrm{C}(\mathrm{D})$, for all $t \in[0, b]$ and $u_{0} \in D_{f}$.

Finally, we shall prove that $u(\mathrm{t})$ is a unique solution of (1). Suppose that

$\bar{u}(t)=u_{0}+\int_{0}^{t} F(t, s) g(s, \bar{u}(s)) d s+\int_{a(t)}^{b(t)} K(t, s) \bar{u}(s) d s$

is another solution of (1).

For $\mathrm{m}=1$ in $(8)$, we have

$\left\|u_{1}(t)-\bar{u}(t)\right\| \leq(L N b+K h)\left\|\bar{u}(t)-u_{0}\right\|$

By mathematical induction, we have

$\left\|u_{m}(t)-\bar{u}(t)\right\| \leq \delta^{m}\left\|\bar{u}(t)-u_{0}\right\| \leq \frac{1}{1-\delta}\left\|u_{1}-u_{0}\right\|$

Since $\delta<1$, then

$\lim _{m \rightarrow \infty} u_{m}=\bar{u}(t)=u(t)$

Thus $\bar{u}(\mathrm{t})=u(\mathrm{t})$

And hence $u(\mathrm{t})$ is a unique solution of (1).

\section{Stability solution of integral equation (1)}

In this section we study the stability solution of (1) by the following theorem:

Theorem 4. If the inequalities (3), (4), (5) and relation (7) are satisfied and $w(t)$ is another solution of (1), then the solution $u(t)$ is stable if satisfies the following inequality:

$\|\mathrm{u}(\mathrm{t})-\omega(\mathrm{t})\|<\epsilon$, for all $\mathrm{t}>0$ and $\in>0$

where 
$\omega(t)=\omega_{0}+\int_{0}^{t} F(t, s) g(s, \omega(s)) d s+\int_{a(t)}^{b(t)} K(t, s) \omega(s) d s$

Proof. Consider

$\|u(t)-\omega(t)\| \leq\left\|u_{0}-\omega_{0}\right\|+\int_{0}^{t} L N\|u(s)-\omega(s)\| d s+\int_{a(t)}^{b(t)} K\|u(s)-\omega(s)\| \mathrm{ds}$

$\leq\left\|u_{0}-\omega_{0}\right\|+(L N b+\mathrm{Kh})\|u(t)-\omega(t)\|$

So

$\|u(t)-\omega(t)\| \leq \frac{1}{1-\delta}\left\|u_{0}-\omega_{0}\right\|$

Putting $\in_{2}=\frac{\epsilon}{\left\|u_{0}-\omega_{0}\right\|(1-\delta)}$, then

$\|u(t)-\omega(t)\| \leq \epsilon$.

So that the solution $u(t)$ is stable for all $t \geq 0$.

\section{Another method of a solution of the integral equation (1)}

In this section, we study the existence and uniqueness solution of (1) by using Banach fixed point theorem.

Theorem 5. Let all assumptions and conditions of Theorem 4 be satisfied. Then the solution $\mathrm{u}(\mathrm{t})$ is a unique of (1) .

Proof. Let $(\mathrm{C}[0, \mathrm{~b}],\|\|$.$) be Banach space. Define a mapping \mathrm{T}$ on $\mathrm{C}[0, \mathrm{~b}]$ by:

$\mathrm{T} u(\mathrm{t})=u_{0}+\int_{0}^{t} F(t, s) g(s, u(s)) d s+\int_{a(t)}^{b(t)} K(t, s) u(s) d s$

Since $g(\mathrm{t}, u)$ and the kernels $\mathrm{F}(\mathrm{t}, \mathrm{s})$ and $\mathrm{K}(\mathrm{t}, \mathrm{s})$ are continuous on the domain(2), then $\left.\int_{0}^{t} F(t, s) d g(s, u(u)) s+\int_{a(t)}^{b(t)} K(t, s) u(s) d s\right)$ is also continuous on the same domain.

i.e. $\mathrm{T}: \mathrm{C}[0, \mathrm{~b}] \rightarrow \mathrm{C}[0, \mathrm{~b}]$.

Now, we claim that $\mathrm{T}$ is a contraction mapping on $\mathrm{C}[0, \mathrm{~b}]$.

Let $u(\mathrm{t})$ and $\bar{u}(t) \in \mathrm{D}$, then

$\|\mathrm{T} u(t)-\mathrm{T} \bar{u}(t)\| \leq \int_{0}^{t} L N\|u(s)-\bar{u}(s)\| d s+\int_{a(t)}^{b(t)} K\|u(s)-\bar{u}(s)\| d s$

Thus

$$
\leq \delta\|u(s)-\bar{u}(s)\|
$$

$\|\mathrm{T} u(t)-\mathrm{T} \bar{u}(t)\| \leq \delta\|u(t)-\bar{u}(t)\|$

Since $\delta<1$, therefore $T$ is a contraction mapping on C[0,b].

Then $\mathrm{T} u(\mathrm{t})=u(\mathrm{t})$ and

$u(t)=u_{0}+\int_{0}^{t} F(t, s) g(s, u(s)) d s+\int_{a(t)}^{b(t)} K(t, s) u(s) d s$

Hence $u(t)$ is a unique continuous solution of (1).

Remark. The Picard approximation method given global solution but Banach fixed point theorem give us the local solution of the integral equation(1).

\section{Some examples only in successive approximation.}

Example A. Consider the following system of integral equation:

$\mathrm{u}(\mathrm{t})=\mathrm{u}_{0}+\int_{0}^{\mathrm{t}} \mathrm{F}(\mathrm{t}, \mathrm{s}) \mathrm{g}(\mathrm{s}, \mathrm{u}(\mathrm{s})) \mathrm{ds}+\int_{\alpha(\mathrm{t})}^{\mathrm{b}(\mathrm{t})} \mathrm{K}(\mathrm{t}, \mathrm{s}) u(\mathrm{~s}) \mathrm{ds}$

with

$u_{0}=0.1, \mathrm{I}=(0,2), \mathrm{s}=3.22$

$\mathrm{F}(\mathrm{t}, \mathrm{s})=2.23 \ln (\mathrm{t}+0.55), \mathrm{g}(\mathrm{s}, \mathrm{u}(\mathrm{s}))=\mathrm{u}(\mathrm{s})+4.22 \mathrm{~s}$

and 


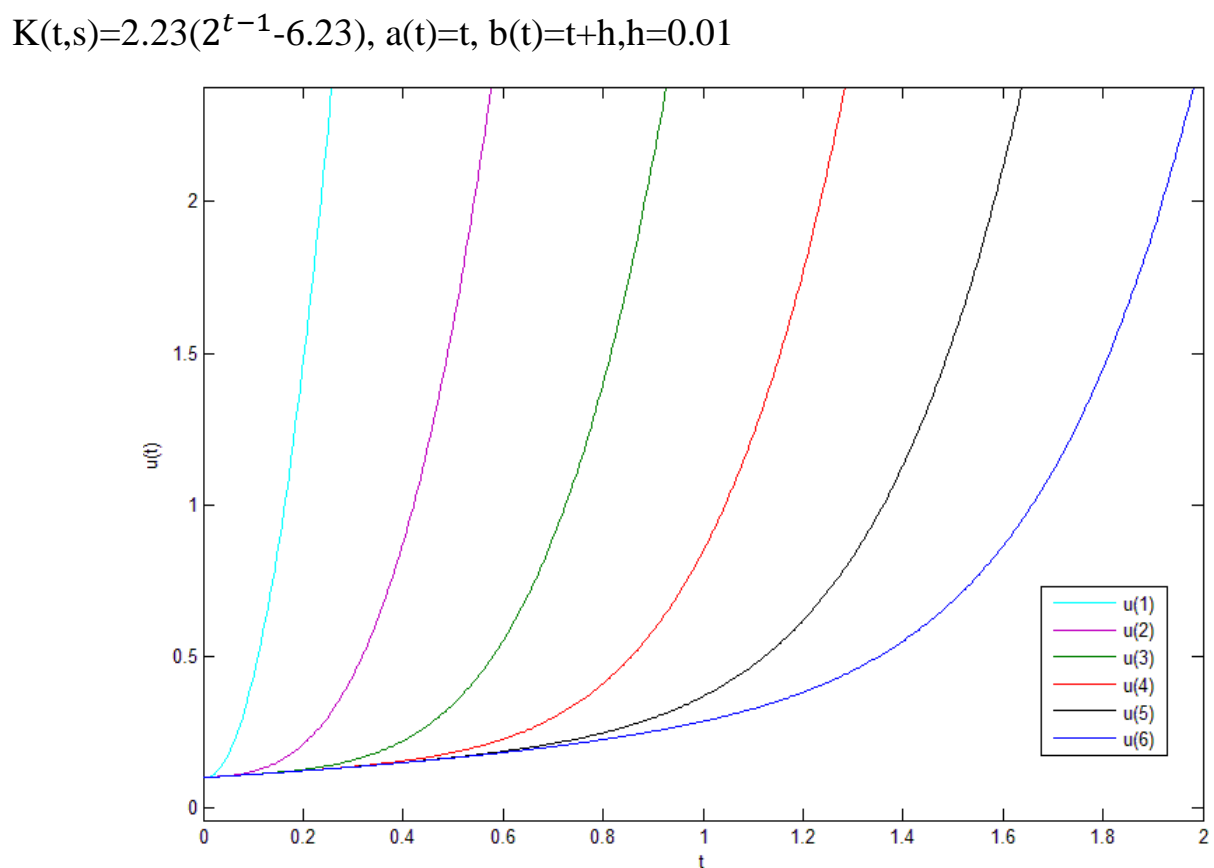

Figure 1. Successive approximation of global solution of (1)

Example B. Consider the same system of integral equation but local interval and another functions.

$\mathrm{u}(\mathrm{t})=\mathrm{u}_{0}+\int_{0}^{\mathrm{t}} \mathrm{F}(\mathrm{t}, \mathrm{s}) \mathrm{g}(\mathrm{s}, \mathrm{u}(\mathrm{s})) \mathrm{ds}+\int_{\alpha(\mathrm{t})}^{\mathrm{b}(\mathrm{t})} \mathrm{K}(\mathrm{t}, \mathrm{s}) u(\mathrm{~s}) \mathrm{ds}$

with

$\mathrm{u}_{0}=0.1, \mathrm{I}=[0,2], \mathrm{s}=3.22$

and

$\mathrm{F}(\mathrm{t}, \mathrm{s})=5.23 \mathrm{e}^{-\mathrm{s}^{2}}, \mathrm{~g}(\mathrm{~s}, \mathrm{u}(\mathrm{s}))=s^{2}-3 \mathrm{~s}$

$\mathrm{K}(\mathrm{t}, \mathrm{s})=5.23 \tan (\mathrm{t}+2)-6.23, \mathrm{a}(\mathrm{t})=\mathrm{t}, \mathrm{b}(\mathrm{t})=\mathrm{t}+\mathrm{h}, \mathrm{h}=0.001$.

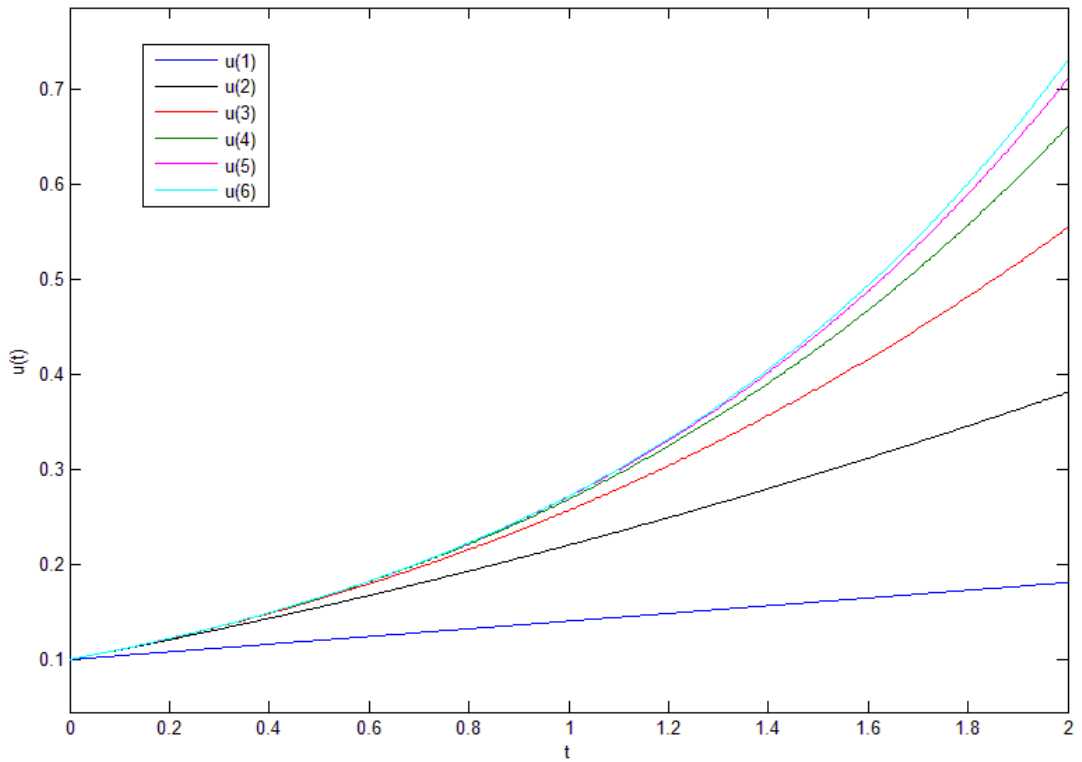

Figure 2. Successive approximation of local solution of (1)

Remark. Successive approximation using MATLAB are show in figure (A) and (B). 


\section{Conclusions}

This paper provided the existence, uniqueness, and stability solution for non-linear system of integral equations. Picard approximation (Successive approximation) method and Banach fixed point theorem have been used in this study which were introduced by [7]. Thus, the non-linear integral equations that we have introduced in the study become more general and detailed than those introduced by Butris [1].

\section{Acknowledgement}

The author is grateful to the reviewers for their suggestions and Prof. Dr. Raad N.

Butris for his scientific orientations, advices, and support

\section{References}

[1] Butris, R. N., Solutions for the Volterra integral equations of the second kind, thesis, M.Sc., university of Mosul, Mosul, Iraq, 1984.

[2] Butris, R. N., and Rafeq, A. Sh., Existence and uniqueness solution for nonlinear Volterra Integral Equation, J. Duhok Univ. Vol. 14, No. 1, (Pure and Eng. Sciences), 2011.

[3] Butris, R. N. and Hussen Abdul-Qader, M. A. Some results in theory integrodifferential equation of fractional order", Iraq, Mosul, J. of Educ. And sci, Vol. 49, 2001.

[4] Goma, I.A. Method of successive approximations in a two-point boundary problem with parameter. Ukr Math J 29, 594-599, 1977. https://doi.org/10.1007/BF01085968

[5] Plaat, O., "Ordinary differential equations", Holden Day, Inc. San Francisco, Cambridge, London, Amsterdam, 1971

[6] Rama, M. M., "Ordinary differential equations theory and applications", United Kingdom, 1981.

[7] Manouchehr Kazemi \& Reza Ezzati, Existence of solutions for some nonlinear Volterra integral equations via Petryshyn's fixed point theorem, Int. J. Nonlinear Anal. Appl., Vol. 9 No. 1, 2018.

[8] Pakhshan Hasan \& Nejmaddin Abdulla, Existence and uniqueness of solution for linear mixed Volterra-Fredholmintegral equations in Banach Space, American Journal of Computational and Applied Mathematics, 9(1), 2019.

[9] Struble, R. A., "Nonlinear differential equations", McGraw-Hill Book Company, Inc, New York, 1962.

[10] Tricomi, F. G., Integral Equations, Turin University, Turin, Italy, 1965. 